\title{
Aplikasi Kehadiran Karyawan Berbasis Android Menggunakan QR Code Scanning dan Location Based Service
}

\author{
Iskandar Yusuf ${ }^{1}$, Henny Leidiyana ${ }^{2^{*}}$ \\ ${ }^{1}$ Program Studi Teknik Informatika STMIK Nusa Mandiri, Jl. Kramat Raya no, 18, \\ Jakarta Pusat, e-mail: iskandaryusuf09@gmail.com; \\ 2 Program Studi Sistem Informasi, Fakultas Teknik dan Informatika,Universitas Bina \\ Sarana Informatika, Jl. Kramat Raya No.98, Jakarta Pusat, e-mail: henny.hnl@bsi.ac.id \\ *Korespondensi: e-mail: henny.hnl@bsi.ac.id
}

Diterima:14 April 2021; Review: 26 Juni 2021; Disetujui: 29 Juni 2021; Diterbitkan: 30 Juni 2021

\begin{abstract}
Employee attendance is an administrative process that is carried out every day. Use of a manual system for events prone to damage or loss. Not to mention employees who forget attendance records, which will cause delays in the flow of employee attendance information. As a solution to the existing problems is by designing an application to make presence using Android-based QR Code Scanning and Location-Based Services (LBS). QR Code technology is very efficient because the code can be read in a very short time using a smartphone while the Location Based Service (LBS) is to prevent employees from making presence outside the area determined by the company. The design of this application produces a paperless system and prevents manipulation of attendance data because in this application it is implemented that one employee only asks for one device ID or smartphone IMEI
\end{abstract}

Keywords: Presence, QR Code, Location Based Service

\begin{abstract}
Abstrak
Kehadiran karyawan merupakan suatu proses administrasi yang dilakukan setiap hari. Penggunaan sistem manual berpotensi terjadinya rawan apabila terjadi kerusakan atau hilang. Belum lagi karyawan yang yang lupa untuk mencatat kehadiran sehingga akan menyebabkan terlambatnya arus infomasi kehadiran karyawan. Sebagai solusi permasalahan yang ada adalah dengan perancangan aplikasi untuk melakukan presensi menggunakan QR Code Scanning dan Location Based Service (LBS) berbasis android. Teknologi QR Code sangat efisien karena kode yang ditampilkan dapat dibaca dalam waktu yang sangat singkat dengan menggunakan smartphone sedangkan Location Based Service (LBS) untuk mencegah karyawan melakukan presensi di luar area yang telah ditentukan oleh perusahaan. Perancangan aplikasi ini menghasilkan sistem yang paperless serta mencegah terjadinya manipulasi data presensi karena pada aplikasi ini diterapkan bahwa satu karyawan hanya diperbolehkan mendaftarkan satu device id atau IMEI smartphone.
\end{abstract}

Kata Kunci: Presensi, QR Code, Location Based Service 


\section{Pendahuluan}

Presensi karyawan adalah suatu proses administrasi yang dilakukan setiap hari, guna mencatat kehadiran karyawan. Dengan adanya presensi karyawan diharapkan dapat mematuhi jam kerja sesuai ketentuan perusahaan. Studi kasus dilakukan pada KFC Harapan Indah dimana proses pencatatan presensi karyawan masih menggunakan presensi manual, yaitu dengan menggunakan kertas presensi yang dieramodern saat ini dinilai kurang efektif dan dari sisi keamanan sistem presensi ini masih sangat rawan apabila terjadi kerusakan atau hilang, sehingga menyebabkan terlambatnya arus infomasi presensi karyawan dalam merekap data (Wulandari et al., 2019)

Lembaga riset digital marketing Emarketer memperkirakan pada 2018 jumlah pengguna aktif smartphone di Indonesia lebih dari 100 juta orang. Dengan jumlah sebesar itu, Indonesia akan menjadi negara dengan pengguna aktif smartphone terbesar keempat di dunia setelah Cina, India, dan Amerika (Rahmayani, 2015). .Android merupakan sebuah sistem operasi smartphone dan tablet yang berbasis linux. Android berubah menjadi platform yang begitu cepat dalam melakukan inovasi seiring perkembangannya. Para pengembang bisa dengan leluasa berkarya dan menciptakan aplikasi yang terbuka untuk digunakan diberbagai macam perangkat. Platform android terdiri dari sistem operasi berbasis linux, sebuah GUI (Graphic User Interface), sebuah web browser dan aplikasi end-user yang dapat di download (Kasman, 2015). Location Based Service adalah layanan layanan informasi yang dapat diakses melalui mobile device dengan menggunakan mobile network, yang dilengkapi kemampuan untuk memanfaatkan lokasi dari mobile device tersebut (Budiman, 2016). Dengan menerapkan layanan berbasis lokasi ini, setiap pengguna android sangat mungkin untuk melakukan pengolahan data yang berupa lokasi pada setiap pengunanya sehingga teknologi ini bisa menjadi solusi dalam membantu sistem presensi yang ada. Selain itu, ada teknologi QR Code yang merupakan kode yang menampilkan tampilan dalam bentuk kode matrik 2D yang dapat menyimpan data dan dapat dibaca dalam waktu yang cukup singkat dengan menggunakan smartphone (Kulkarni, 2020).

Penerapan Location Based Service (LBS) dan QR Code scanning pada sistem presensi dirasa lebih efektif karena akan menghasilkan sebuah aplikasi berbasis android yang akan menutupi permasalahan sistem presensi yang ada. Aplikasi ini dapat memudahkan karyawan alam melakukan presensi, dimana dengan aplikasi ini karyawan tidak perlu lagi melakukan presensi secara manual dengan menulis dikertas presensi, melainkan hanya perlu membawa perangkat smartphone yang telah terinstal aplikasi ini. Dengan membuat aplikasi sistem aplikasi abensi berbasis android menggunakan validasi kordinat lokasi, data kehadiran karyawan dapat termonitor secara realtime (Yusuf \& Afandi, 2020). Cara kerja aplikasi ini ialah berdasarkan lokasi karyawan tersebut berada, saat karyawan berada di titik koordinat area perusahaan maka karyawan dapat melakukan presensi dengan menscan QR code sedangkan saat karyawan berada diluar area perusahaan maka karyawan tidak dapat melakukan presensi.

\section{Metode Penelitian}

Pada penelitian ini penulis menggunakan model Waterfall sebagai model pengembang sistem, dikarenakan kebutuhan user telah terdefinisi secara jelas dan tahap-tahap pada model Waterfall terstruktur secara jelas. Metode ini digunakan dalam penelitian ini karena metode ini memiliki urutan dari satu tahap ke tahap berikutnya supaya tidak terlewatkan atau meminimalisir kesalahan dan mudah dipahami (Hidayanti et al., 2020). Metode Pengembangan Aplikasi yang digunakan pada pengembangan perangkat lunak ini menggunakan model water fall (Sukamto \& Shalahuddin, 2016) yang terbagi menjadi 5 tahapan yaitu

\section{Analisa Kebutuhan Software}

Software yang digunakan untuk membangun aplikasi ini menggunakan Visual Studio Code sebagai code editor serta compiler dan Firebase sebagai databasenya.

2. Perancangan

Perancangan perangkat lunak menggunakan sistem pemodelan Unifield Modeling Language (UML) dengan menggunakan draw.io.

3. Pembuatan Kode 
Aplikasi ini dibangun menggunakan Bahasa pemrograman Dart, menggunakan Visual Studio Code.

4. Pengujian

Pengujian pada pembangunan aplikasi ini menggunakan Black Box Testing.

5. Pendukung

Menggunakan GitHub untuk pengembangan perangkat lunak yang menggunakan sistem kendali Git.

\section{Hasil dan Pembahasan}

Presensi di KFC Harapan Indah yang berjalan saat ini adalah, diawali dengan karyawan yang telah mendapatkan jadwal bekerja akan mendapatkan kertas presensi. Kertas presensi ini sebelumnya telah dicatat di buku besar presensi oleh Chief Cashier untuk dicatat nama dan nik karyawan. Proses presensi karyawan dilakukan pada saat karyawan datang, yaitu 15 menit sebelum karyawan bekerja. Dalam pelaksanaannya, presensi karyawan tidak boleh diwakilkan yang artinya karyawan tersebutlah yang harus melakukan presensi itu sendiri.

Kertas presensi harus berada di area kantor, karena akan dicek dan ditandatangani oleh Manajer. Setelah 1 bulan penuh presensi, seluruh kertas presensi akan direkap oleh Chief Cashier, proses rekap dimulai dengan menghitung kehadiran, sakit, izin, alpa, dan cuti. seluruh kertas presensi dikirim melalui kurir ke bagian HRD untuk di proses mengenai penggajian karyawan.

\section{Analisis Kebutuhan Software}

Aplikasi kehadiran adalah aplikasi berbasis android untuk melakukan presensi pada karyawan KFC Harapan Indah. Berikut ini spesifikasi kebutuhan (system requirement) dari aplikasi kehadiran KFC;

Halaman Karyawan:

1. Karyawan melakukan scan QR code

2. Karyawan melakukan presensi masuk dan keluar

3. Karyawan dapat mengajukan izin/cuti

4. Karyawan dapat melihat status izin/cuti

Halaman Admin:

1. Admin dapat mengelola data daftar izin/cuti karyawan

2. Admin dapat mengelola data karyawan

3. Admin dapat melihat presensi harian

4. Admin dapat merekap presensi bulanan

Pemodelan yang digunakan dalam penelitian ini adalah UML. UML yang telah dirancang dapat membuat perangkat lunak sesuai dengankebutuhan institusi pemakai (Putra \& Andriani, 2019).

Diagram yang digunakan dalam pemodelan proses bisnis dalam penelitian ini pertama adalah usecase.

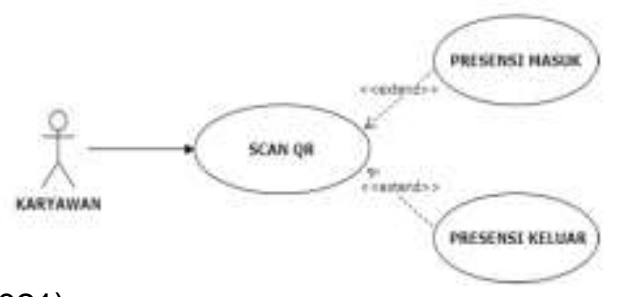

Sumber : Hasil Penelitian (2021)

Gambar 1. Use Case Diagram Halaman Karyawan Scan QR 
Diagram usecase menjabarkan aktor yang terlibat dan hal-hal yang dapat dilakukan pada sistem. Pada sistem kehadiran karyawan terdapat dua aktor yang melakukan interaksi terhadap sistem yaitu karyawan dan admin.

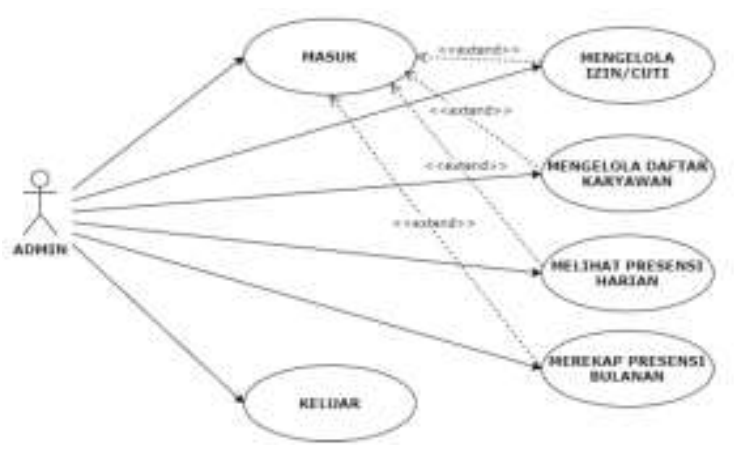

Sumber : Hasil Penelitian (2021)

\section{Gambar 2. Use Case Diagram Halaman Admin}

Activity diagram dibuat berdasarkan rancangan use case diagram menjelaskan tentang proses yang dapat dilakukan oleh karyawan seperti pada gambar 3 dan admin pada gambar 4 .

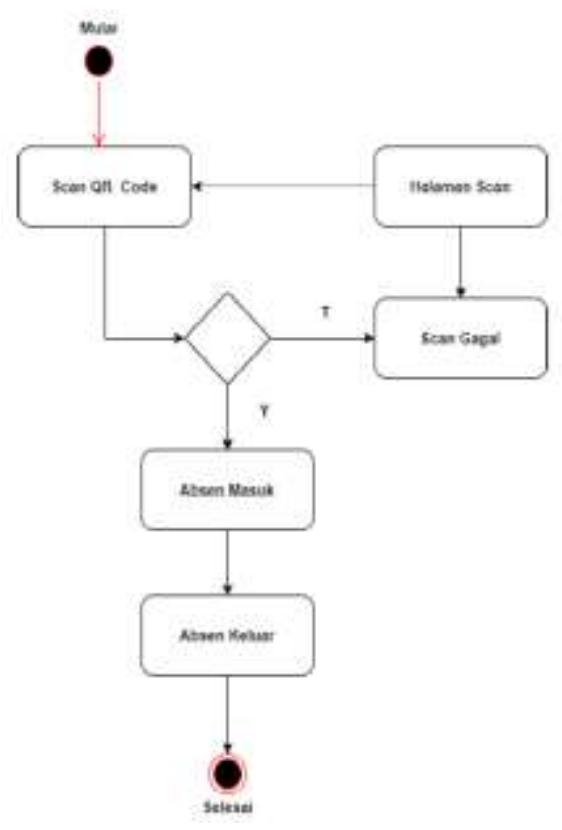

Sumber : Hasil Penelitian (2021)

Gambar 3. Diagram Activity Kehadiran Karyawan

Berdasarkan acticity diagram, karyawan melakukan presensi dengan scan QR Code, jika gagal maka diulang. Untuk absen keluar prosesnya sama. 
Sumber : Hasil Penelitian (2021)

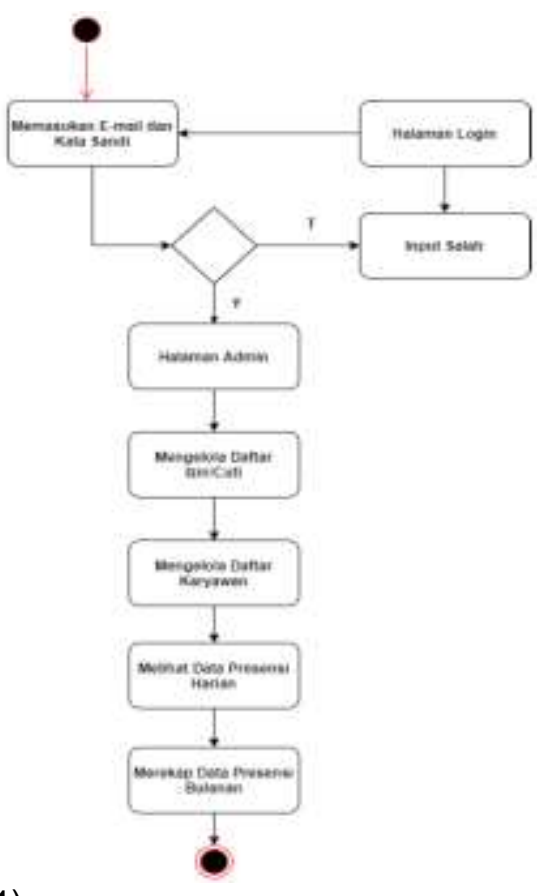

Gambar 4. Diagram Activity Kelola Admin

Untuk masuk ke aplikasi admin masukkan email dan password. Jika berhasil akan tampil menu utama dan dapat mengelola data karyawan, pengajuan cuti, dan presensi harian dan bulanan

\section{Database}

Perancangan basis data menghasilkan pemetaan tabel-tabel yang digambarkan dengan Entity Relationship Diagram (ERD) seperti yang ditunjukkan Gambar 5. Terdiri dari empat entitas dengan masing-masing atribut dan relasinya. Entity Relationship Diagram (ERD) merupakan gambaran yang menghubungkan antara objek satu dengan objek yang lain dalam dunia nyata (Utami \& Hartanto, 2005)

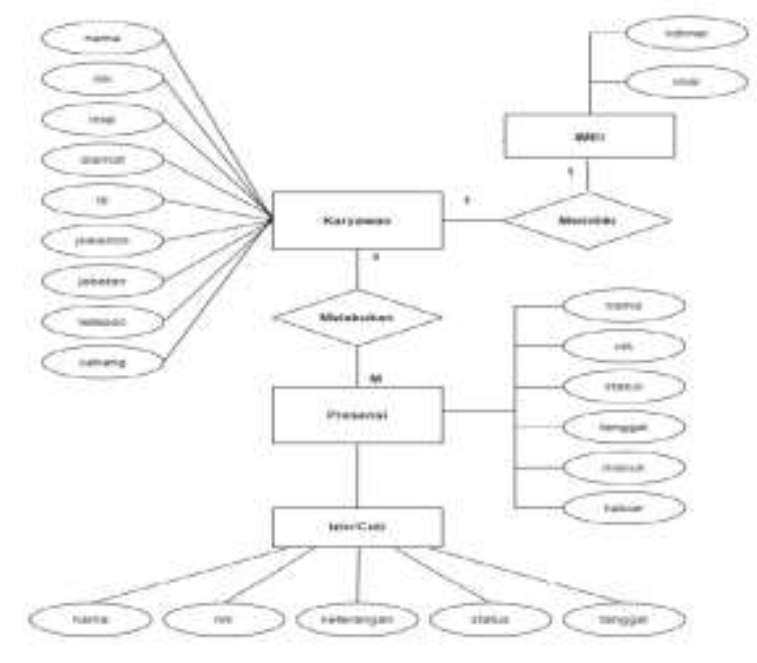

Sumber : Hasil Penelitian (2021)

Gambar 5. ERD Aplikasi Kehadiran Karyawan 


\section{Class Diagram}

Berikut ini adalah objek-objek yang teridentifikasi dari sistem presensi karyawan:
a. Karyawan
b. IMEI
c. Presensi
d. Izin/cuti

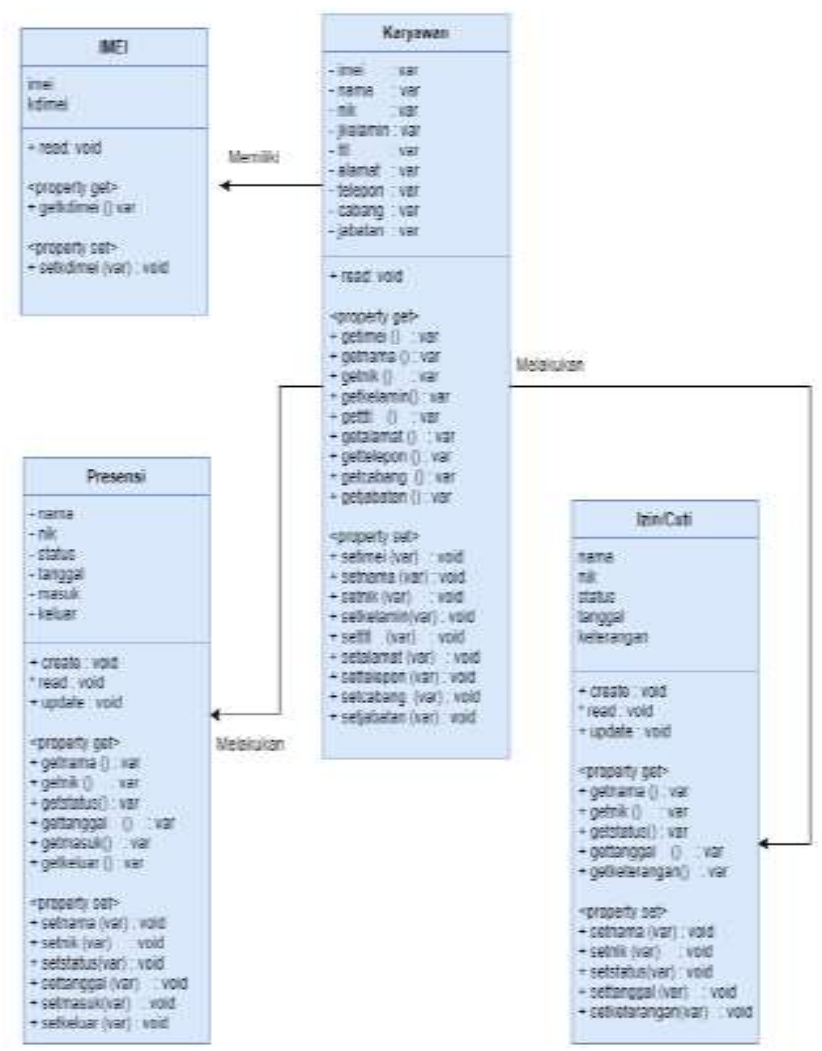

Sumber : Hasil Penelitian (2021)

Gambar 6. Diagram Class Aplikasi Kehadiran Karyawan

\section{Perancangan Antar Muka (User Interface)}

Pada bagian ini menjelaskan tentang rancangan antarmuka untuk pengguna yang terdapat pada Aplikasi Kehadiran Karyawan. Menu utama berisi pilihan pengguna yang login sebagai Admin atau Karyawan. Untuk masuk ke aplikasi maka admin masukkan email dan password, jika berhasil akan tampil menu seperti pada Gambar 7. 


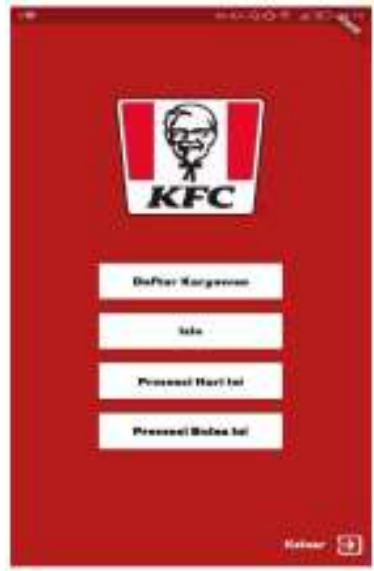

Sumber : Hasil Penelitian (2021)

Gambar 7 Tampilan Menu Admin

Admin dapat melihat daftar karyawan dengan memilih menu Daftar Karyawan. Presensi hari ini dapat dilihat dengan memilih menu Presensi Hari ini atau memilih menu Presensi Bulanan seperti pada Gambar 8.

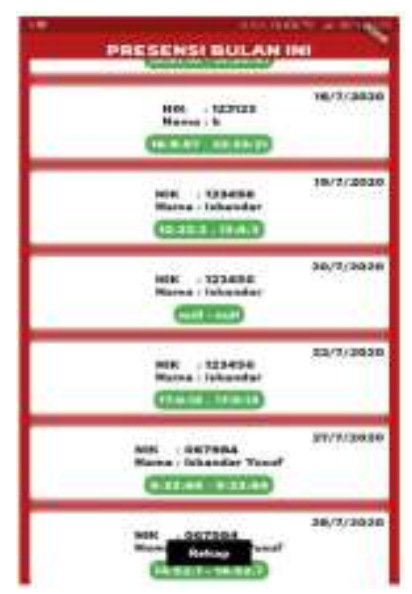

Sumber : Hasil Penelitian (2021)

Gambar 8 Tampilan Menu Presensi Bulanan

Gambar 9 adalah Tampilan aplikasi untuk karyawan yang di dalamnya terdapat dua tombol untuk kehadiran dan pengajuan cuti 


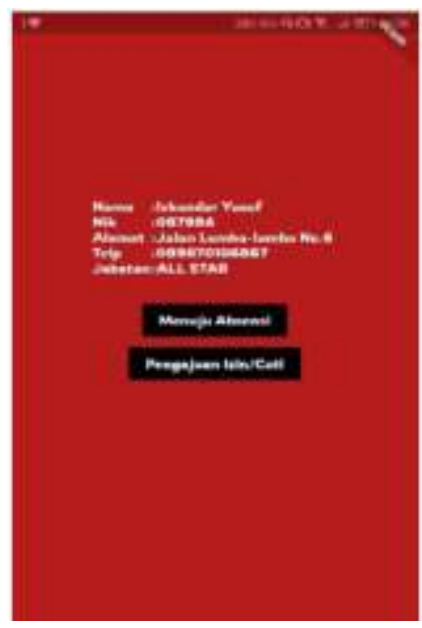

Sumber : Hasil Penelitian (2021)

Gambar 9 Tampilan Menu Daftar Karyawan

Jika pilih Menuju Absensi maka akan tampil Scan QR Code kemudian Karyawan dapat melakukan absensi tampil Presensi Masuk seperti gambar 10 dan jika selesai waktu kerja dapat melakukan presensi keluar di halaman yang sama

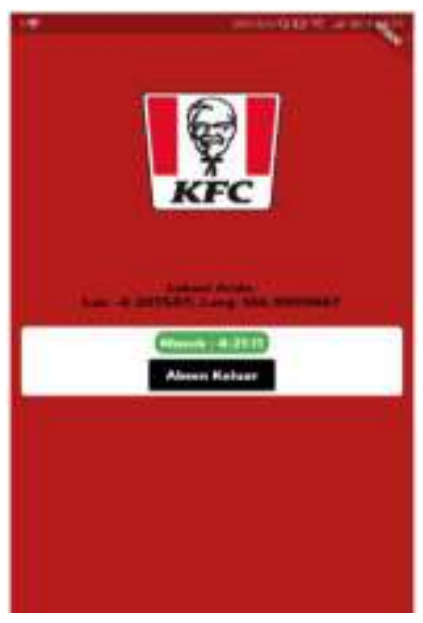

Sumber : Hasil Penelitian (2021)

Gambar 10 Tampilan Menu Presensi Masuk

Karyawan juga dapat mengajukan cuti dengan memilih tombol Pengajuan cuti dan akan tampil seperti gambar 11. Karyawan harus mengisi keterangan cuti atau izin dan memilih tanggalnya. 


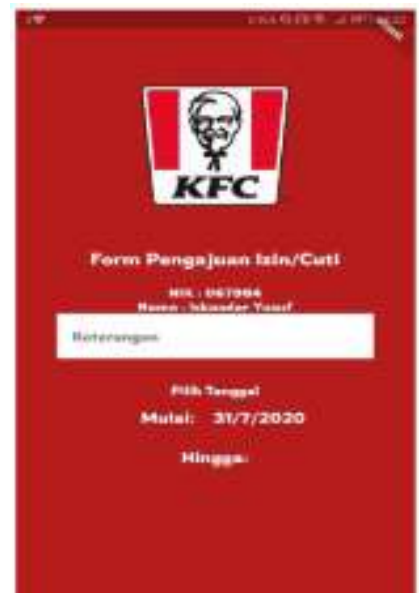

Sumber : Hasil Penelitian (2021)

Gambar 11 Tampilan Menu Form Pengajuan Izin/Cuti

\section{Kesimpulan}

Dari hasil rancang bangun aplikasi yang dibuat, maka dapat diuraikan beberapa kesimpulan sebagai berikut:

1. Perancangan aplikasi kehadiran berbasis android ini membuat presensi lebih efektif dan efisien dari sistem sebelumnya.

2. Saat masuk menu presensi karyawan, ada fitur keamanan dimana hanya mengizinkan satu device untuk satu karyawan berdasarkan IMEI handphone.

3. QR Code dapat dibaca hanya dengan handphone yang sudah masuk ke dalam aplikasi Kehadiran KFC.

4. Location Based Service membuat sistem presensi menjadi lebih teratur.

5. Sistem ini telah diuji secara penggunaan dan hasilnya lebih efisien karena sifatnya yang paperless.

\section{Daftar Pustaka}

Budiman, E. (2016). Pemanfaatan Teknologi Location Based Service Dalam Pengembangan Aplikasi Profil Kampus Universitas Mulawarman Berbasis Mobile. ILKOM Jurnal IImiah, 8(3), 137-144. https://doi.org/10.33096/ilkom.v8i3.81.137-144

Hidayanti, N., Widyawati, W., Fatullah, R., \& Budiono, B. (2020). Rancang bangun aplikasi monitoring kegiatan kuliah kerja mahasiswa berbasis android di Universitas Banten Jaya. Teknika: Jurnal Sains Dan Teknologi, 16(2), 267. https://doi.org/10.36055/tjst.v16i2.8680

Kasman, A. D. (2015). Trik Kolaborasi Android dengan PHP \& MySQL. Lokomedia.

Kulkarni, K. S. (2020). QR CODE BASED TECHNIQUE FOR DATA TRANSFER FROM COMPUTER. June, 3313-3317.

Putra, D. W. T., \& Andriani, R. (2019). Unified Modelling Language (UML) dalam Perancangan Sistem Informasi Permohonan Pembayaran Restitusi SPPD. Jurnal Teknolf, 7(1), 32. https://doi.org/10.21063/jtif.2019.v7.1.32-39

Rahmayani, I. (2015). Indonesia Raksasa Teknologi Digital Asia. https://kominfo.go.id/content/detail/6095/indonesia-raksasa-teknologi-digitalasia/0/sorotan_media

Sukamto, R. A., \& Shalahuddin, M. (2016). Rekayasa Perangkat Lunak Terstruktur dan 
Berorientasi Objek. Informatika.

Utami, E., \& Hartanto, A. D. (2005). Sistem Basis Data Menggunakan Microsoft SQL Server 2005. Andi Offset.

Wulandari, R., Danuri, \& Jaroji. (2019). Aplikasi Pengelolaan Presensi Guru Berbasis Web Di. 5, $165-170$.

Yusuf, D., \& Afandi, F. N. (2020). Aplikasi Absensi Berbasis Android Menggunakan Validasi Kordinat Lokasi Dan Nomor Handpone Guna Menghindari Penularan Virus Covid 19. EXPERT: Jurnal Manajemen Sistem Informasi Dan Teknologi, 10(1), 16-22. https://doi.org/10.36448/jmsit.v10i1.1492 